\title{
Exploring Methodology for Sharia Subject in Accordance with Dini Integrated Curriculum
}

\author{
Firdaus Abdul Fatah, Khadijah Abdul Razak, Hafizhah Zulkifli \\ Faculty of Education, Universiti Kebangsaan Malaysia \\ Email: firdausABF@gmail.com
}

\begin{abstract}
Ensuring teaching objectives to be achieved among pupils is not an easy task, especially if the subject is newly introduced to them. Sharia subject in this research, is using Dini Integrated Curriculum (DIC) which was introduced not long ago in 2015. It is unique that this subject is taught in the Arabic Language and not the mother tongue of Malaysians. This research applied quantitative method. Data was collected through interviews with 8 research respondents and then triangulated by observations and document analysis. Research findings showed that teachers used methods connected to games and active class participations. The implications of this research revealed that teaching techniques for this subject can be varied and not mundane.
\end{abstract}

Keywords:

Sharia, teaching techniques, Dini Integrated Curriculum, active learning.

\section{Introduction}

Globalization has given a lot of influences in the system today. This globalization effects have made education world to accept the challenges that information nowadays can be accessed at the end of one's fingertips. The world is moving very fast and so does the information technology. Teachers must also be well aware that the pupils in this era are of those who can have quicker access to information through information technology. Just a click with their fingertips and they will be served with wide range of information in front of their eyes.

This situation actually creates a lot of implications. Positively the globalization has given us an opportunity for knowledge sharing globally, in line with Sharia subject itself where its nature is a knowledge which discusses an overall understanding about the law of religion regarding the do's and don'ts relatable to living. (Mahmood Zuhdi, 1997).

However, pupils are not that interested to learn anything related to religious matters including Sharia subject. It is also perceived as a dull subject since teaching techniques used in this subject are not up to date and do not follow any $21^{\text {st }}$ century learning techniques such as Gallery Walk, Round Robin, Timed Pair and Share, just to name a few. Most of the times, teachers are still using the conventional chalk and talk method (Islamic Education Division 2017, Grunwald Associates LLC 2010, Norasmahani et al 2016) which is actually will bore the pupils. (Mwathwana. Mungai, Gathumbi \& George 2014)

Other than that, teachers should always make an effort to master themselves in all aspects to increase the effectiveness of their teachings in accordance to the education development towards the $21^{\text {st }}$ century learning (Amran, N. and Rosli, R., 2017, 2017, Rusdin, N. M., \& Ali, S. R 2019)

\section{Sharia subject in Malaysian Scenario}

Sharia subject is a knowledge with the purpose to develop and mould Muslim pupils to comprehend, practice and appreciate Islam as a whole. Through this subject, pupils will be given ample knowledge and understanding about al hukum or rules of current inquiries so that they will be able to develop 
themselves and the community according to AlQuran an Al- Sunnah.

In Malaysia, before Dini Integrated Curriculum was implemented, this subject had actually been taught in general in Religious Education at the primary level. There was Islamic Sharia subject taught at secondary schools as an elective as well. However, when DIC was introduced, Sharia subject has become a compulsory subject at any religious stream classes at Government Aided Religious School (GARS).

\section{Dini Integrated Curriculum}

The true meaning of Integrated Curriculum has long being discussed among researchers and many have shared their views on what this means. Therefore, the development of Integrated Curriculum is actually the unity of ideas concerning various disciplines (Beane 1997, Rennie, Venville and Wallace 2013) where teachers' motivation towards creativity in conveying the knowledge to the pupils are uplifted. (Gresnigt et al 2014).

Dini Integrated Curriculum was recently introduced in 2015. This Curriculum sets a purpose to strengthen the education system at the religious schools in Malaysia which are registered with the Ministry of Education and these schools are known as Government Aided Secondary Schools. By implementing this curriculum, Sharia subject has become more structured.

This curriculum uses Arabic Language as a medium in conveying the content of the subject offered to the pupils. The subjects are Lughatul Arabiah Muasarah, al -Sharia, Usul Al- din, Manahij al-Ulum al-Islamiah and al-Adab wal Balaghah (Fatah, F. A et all 2019, MOE 2015). The newly introduced curriculum is actually an added value in the Malaysian Education system. According to (Kereluik et al 2013), this curriculum should always expand and be modified according to the development in the current knowledge especially in the $21^{\text {st }}$ century.
In other words, Dini Integrated Curriculum actually combines religious curriculum into the national curriculum in Malaysia without any isolations. Hence, pupils in the religious education streams have the same chances as of those in the Science and Literature streams to further their studies to the tertiary level (MOE 2015).

Challenges faced by the teachers in Sharia subject.

The efforts in ensuring the understanding towards Dini Integrated Curriculum Sharia subject is a real challenge due to the fact that the teachers have to do the teachings in Arabic Language. It is a tough task since Arabic Language is not the mother tongue of Malaysian pupils. This matter was discussed in the research by Kamarulzaman et al (2018) which involved 466 pupils and 146 teachers from Government Aided Religious Schools all over Malaysia, where the infrastructure facilities and environmental factors are only at intermediate level. This is definitely not a good situation to be executing the curriculum objectives. In fact, Awatif et al (2019) found that teachers' competency in Arabic Language of GARS needs to be improved even though pupils' perception towards this Curriculum implementation is high ( Siti Afifah , Ummu Dhabitah and Kamarulzaman (2017).

In this Sharia subject, there are some specific terms in Arabic that need explanation in the pupils' first language. In fact, this subject discusses in depth very particularly rules related to current conditions. (Dasima et al 2018: Farah Farhana, Mohd Anuar and Firdaus 2019, Mohd Yusri 2019).Thus, the use of the second language in teaching is consistent with the content and language intergrated approach (CLIL) because teachers do not purposely teach the language, instead use the language as a medium of conveying the subject to the pupils (Marsh.D , \& Lange G-2000). Research on CLIL found that this approach did not produce encouraging results (Sergiotto 2017, Suwnnopharat and Chinokul 2015) and this further drove the teachers to explore the best methods so that pupils would have an interest in the subject and consequently produce good results. 


\section{Research Objectives}

Generally, this research is to explore how teachers convey the content of Dini Integrated Curriculum Sharia subject.

\section{Methodology}

This research is qualitative where it used study case design. According to Yin (2002), case study is an empirical research design with a purpose to explore the contemporary phenomenon in a real life context. Therefore, this research is to discover how teachers of Dini Integrated Curriculum Sharia subject apply methods of teaching at government aided schools in Malaysia. This research used 3 methods of data collection which involved interviews, observations and document analysis. These data were also triangulated through interviews with the administrative officers and pupils. Data collection through these sources would then produce qualitative data. All data acquired would be administered according to method procedures of qualitative standards approaches.

\section{The selection of research respondents}

In this research, respondent selection strategy used is called the snowball strategy, based on the criteria being set; in which the respondents must be among qualified teachers in Selangor. The quantity of the respondents was not determined earlier since the principle of this research selection is considered enough for qualitative research when the information obtained has reached its saturated stage. (Guba \& Lincoln 1998, Merriam 2001, Silverman 2002). At the end, there were 8 respondents chosen from specific schools in Selangor.

\section{Data collection and processing methods}

The main source of data collection was through semi structured interviews with 8 main respondents. Subsequently the data obtained were supported by several other methods such as observations towards teaching and learning sessions conducted by the teachers and later on carrying out document analysis which were considered relevant to the study. Other than that, the collection of this prime data was supported by seconds source which was gained through supporting interviews with fellows of research respondents, the school administrative and pupils of these respondents.

All information gathered through previous sources mentioned were transcripted and analyzed in depth to produce meaningful units which then, were transformed into codes. These codes were analyzed and compared until categories and themes were created. This comparison process were carried out comparatively constant until it reached saturated level (Merriam 2001, Yin 2002)

\section{Validity and Reliability}

Some approaches were used to ensure verification and reliability of this research, for example triangulation, member's check, peer review, prioritizing ethical issues by applying for permission to carry out researches from the authority, confidentiality of the respondents and locations, clear insights towards the chosen theories and developing complete and overall data files.

\section{Research findings}

Research finding revealed that the research respondents were really into doing the responsibility of ensuring the language content of Sharia subject was well conveyed according to what this curriculum stated. Basically, the teachers' collaborative efforts were materialized based on the teaching pedagogy's of the respondents, and also their efforts in trying to get to know their pupils.

To have a clearer view, the findings are translated into the table below. 
Table 1: Findings on how learning content of Dini Integrated Curriculum Sharia Subject

\begin{tabular}{|l|l|l|}
\hline Categories & Themes & Codes \\
\hline Teachers' pedagogy & $\begin{array}{l}\text { Interesting teaching } \\
\text { approaches }\end{array}$ & $\begin{array}{l}\text { Games } \\
\text { Singing } \\
\text { Scrapbooking } \\
\text { Simulations }\end{array}$ \\
\hline Getting to know pupils & Personal details & $\begin{array}{l}\text { Background } \\
\text { Performances } \\
\text { Learning styles of the pupils }\end{array}$ \\
\hline
\end{tabular}

Research respondents were seen to be using all types of methods in their teaching and learning sessions. Active learning activities such as games were used. For illustration, Respondent \#4 used ball catching activity in a group where it involved many pupils participating during the session, where the last pupil to catch the ball was given a task based on the lesson on that day. The respondent explained that "Pupil A would have to pass a ball to a friend, the one who caught the ball answered the question related to the task given, and when he answered, he indirectly remembered the lessons he learned previously. From the feedback by the form 3 pupils, they loved this game and anticipated towards it. They believed through such games, they would remember the topics learned and it was also fun and motivating ".

Meanwhile, Respondent \#2 created a game called habibiey habibaty. This game needs the pupils to stay focus on the requirements of the questions and they are supposed to always move towards the finishing line (R2/DBV/Games).

For another method like singing, many ways had been implemented by the research respondent. There was also a respondent who allowed the pupils to answer questions by creating rhythm based on their creativity. Nonetheless, it was up to the respondent to determine which rhythm to use in order to impose some controls over the session ( $R$
2). The use of songs and music in a lesson was proven to be effective as admitted by Respondent \#4. "I noticed that pupils tend to forget what we teach if there are no activities involved. But through certain activities I created along with different techniques, the pupils would remember the lesson well, in fact till they go to their Form 5 and they said they remembered my songs well" (TBU/R4/TB2:1001).

Besides singing, another interesting technique used was scrapbooking. By creating scrapbooks pupils were involved in Higher Order Thinking Skill which is definitely another element of $21^{\text {st }}$ learning which relates to inquiry and creating. Respondent \#3 also said, “...when pupils do scrapbooks, they need to find all sorts of information. They will have to work in groups to find answers and later on present their end product. They also can ask people and they normally love this activity" (R3/IV3 :1025).

To stimulate pupils in involving themselves in teaching and learning activities, all research respondents ensured that all pupils participated in the simulations on their learning related to regulations that concerned their daily lives. "Yes, sometimes I do demonstrations on matters that are rarely done such as Khauf prayer, Khusuf prayer. Then those pupils followed, they also did through simulation" (TBU/R2/TB1:301). 
Another effect used by the respondent to attract the pupils' attention in understanding the lesson was, to ask the pupils to come up with notes in the form of I-Think map. For example, "Doing notes and learning are both acceptable, err the I-Think maps" (TBU/R8/TB2: 92).

The second aspect done by the respondent in their attempts to gain pupils' attention was by knowing the pupils better or get closer to them. All respondents admitted that they needed to know all their pupils in order to approach them. The basic thing to do is to know their names. However Respondent \#1, Respondent \#6 and Respondent \#8 admitted that although they recognised the pupils, they felt it was difficult to rememorize all the names because they were too many to remember. "...well, I did try to know their names, but I do have difficulty in remembering all names; like how people might put it. Sometimes we could learn the toughest thing like medicine and all but when it comes to remembering names, we failed. But ironically, when the kids are no longer in school, I would remember their respective names" (R6/IV2:68).

The next matter being stressed by the research respondents concerned the pupils' backgrounds which were related to the pupils' family conditions and academic performances. These details would help the teachers to identify the best possible ways of teaching strategies that suited the pupils. "One of the ways to know the pupils is by asking where they are from. I would find out where they were brought up, if they are from the village, I would adjust accordingly. This is a town. Then, I would find out about the siblings. This also has an impact. The third and the most important is, I'll check if there are orphans and asnaf among the pupils. If there any in the class, I'll make sure I know how many of them. In this way I will know to what extent I could possibly provide and do for them. After all these, then only I go through their academic performances. This is normally the last part because it does not really matter. What matters is the fact that they are already here, it means they are obedient enough to their parents to learn and study Arabic Language at this school (R6/IV2: 101).

Moving on, the next personal details would be the pupils' learning styles. Different learning styles would necessitate different teaching methods. The research respondents insisted that teachers should be aware of the pupils' learning styles. Respondent \#2 explained that, "For example, if we teach the conventional method, we follow the traditional way. Pupils might only be auditory learners; they could just listen. There were pupils who fell asleep in class. So, I changed to the interactive activities and surprisingly those were the ones who finished first. Through this, I learned that these pupils were the kinaesthetic kind of people, they needed active involvement in a task since they could finish on time during such lesson" (R2/IV2:10). Other than that, the respondents realised that different learning styles would depend also on the timing of the teaching sessions. Respondent \#1 further explained, “...in the morning, my methods would differ than those of $10 \mathrm{am}, 11 \mathrm{am}$. The $1.00 \mathrm{pm}$ or $2.00 \mathrm{pm}$ learning sessions would be conducted accordingly to suit the time. The afternoon pupils would normally feel sleepy so class activities must be kinaesthetic."

\section{Discussion and summary}

Efforts put in by the research respondents in carrying out active teaching and learning methods were proven to be effective in driving the pupils' attention towards the learning content. At the same time, numerous efforts put forward by the teachers portrayed that the teaching and learning processes were conducted in such a way that it was pupilcentred and not the otherwise. This fact therefore leads to the realisation that religious subjects are not necessarily taught in a traditional boring ways. These pupil- centred activities increase pupils' curiosity in learning and stimulate healthy competitions among the pupils to answer and participate in the class activities.

Subsequently by executing interesting teaching methods, research respondents proved that Sharia subject can be taught in many ways according to 
the teachers' creativity. In fact Higher Order Thinking Skills elements are also absorbed into teaching and learning whenever pupils are facilitated to practise self-access learning when they have to seek for information on their own in solving any inquiries about the lessons, before they are given explanation by the teachers. The use of IThink maps is also encouraged.

Apart from this, teachers' skills in getting to know their pupils will eventually make their attempts to approach the pupils will be easier and naturally they will be able to grasp the pupils' attention towards their lessons. It is undeniable that, pupils tend to focus more to the teachers who show some efforts to see who they really are (al - Banna 2003, Faez 2012, Gamal 2003)

Additionally, teachers can also easily realise the conflicts or issues faced by the pupils regarding learning. There are many aspects that can be considered by teachers in order to know their pupils. Teachers can identify their pupils' academic performances based on their previous results. This can be obtained from other teachers who taught them in the previous years and the pupils' academic records. The research respondents also showed concerns towards the pupils' learning styles.

By looking into the pupils' backgrounds, suitable methods which fit to attract the pupils' attention can be easily identified. Based on all efforts shown by the teachers, it can be concluded that Sharia subject teachers at the Government Aided Religious Schools have actually tried their best to gain pupils' focus towards this subject in particular and for this reason materialises the objectives of Dini Integrated Curriculum. This research has also indirectly shown that the teachers have mastered multiple shapes of pedagogical content knowledge that are needed as mentioned in the discussion by Grossman (1989), Reillard (2012) and Shulman (1987).

Research limitations and implications
This research is qualitative and findings could not be generalised. It is limited to respondents from only one state. Hence, future researches can be done in quantitative form representing Sharia teachers in Government Aided Religious Schools all over Malaysia. The scope of this research can also be expanded to other subjects offered in this curriculum.

This research gives implications specifically to those teaching Sharia subject using Dini Integrated Curriculum that:

1. This subject can be taught in various interesting ways besides the chalk and talk method.

2. This subject can be fun for both teachers and pupils if the teachers allow trust and flexibility for the pupils to explore the right solutions for any matters that they do not understand.

3. Every teacher should have empathy and understanding for the pupils by taking into consideration of the personal details obtained, thus making teaching easier since the details can be used as guidance in preparing any suitable teaching methods to fit the pupils needs.

\section{References:}

[1] Al-Banna, J. (2003). Al-Islām Dīn Wa Ummah Laisa Dīnan Wa Daulatan. Kairo, Dar Al-Fikr al-Islami.

[2] Amran, N. and Rosli, R., 2017. Teachers' Understanding in 21st Century Skills. Prosiding Persidangan Antarabangsa Sains Sosial \& Kemanusiaan.an (p. 412). Selangor: Pusat Pengajian Teras, Kolej Universiti Islam Antarabangsa Selangor

[3] Beane, J. A. (1997). Curriculum integration: Designing the core of democratic education. Teachers College Press.

[4] Faez, F. (2012). Diverse teachers for diverse students: Internationally educated and Canadian born teachers' preparedness to teach English language learners. 
Canadian Journal of Education/Revue canadienne de l'éducation. 35:3, 64-84

[5] Fatah, F. A., Razak, K A., Lubis, M.A., \& Surip N. A. (2019). Al-Quran Wal-Hifz's Heterogeneity of Teaching Methods among Dini Integrated Curriculum Sharia Teachers. Creative Education. 10. 25842592. 10.4236/ce.2019.1012186.

[6] Gamal Abdul Nasir Zakaria. 2003. Ibnu Sahnun Al-Qabisi, Ibnu Khaldun; PrinsipPrinsip Pendidikan Islam. Bentong Pahang: BTS Publication dan Distributers Sdn Bhd

[7] Ghani, Kamarulzaman \& Ismail, Zawawi \& Hashim, Azmil (2018). Persekitaran Bahasa Arab dalam Pelaksanaan Kurikulum Bersepadu Dini di SABK. Jurnal Sultan Alaudin Sulaiman Shah (Speccial Issue 2018)

[8] Ghazali, N., 2017. Pendidikan Islam di Malaysia: Analisis kepentingan penghayatan mazhab Syafie (Islamic education in Malaysia: Analyzing the significance of appreciating the Shafi'i school). Geografia-Malaysian Journal of Society and Space, 12(4).

[9] Gresnigt, R., Taconis, R., van Keulen, H., Gravemeijer, K., \& Baartman, L. (2014). Promoting science and technology in primary education: a review of integrated curricula. Studies in Science Education, 50(1), 47-84.

[10] Grossman, P.L. 1989. A Study in contrast: Sources of Pedagogical Content Knowledge for secondary English. Journal of Teacher Education 40(5): 24-31.

[11] Guba, E \& Lincoln,. 1998 Competing Paradigm Qualitative Research. San Fransisco: Jossey-Bass Publishers.

[12] Islamic Education Division. (2015b). Maklumat asas pelaksanaan kurikulum bersepadu dini. Basic Information On the Implementation of Dini Integrated Curriculum. Ministry of Education Malaysia.
[13] Kereluik, K., Mishra, P., Fahnoe, C., \& Terry, L. (2013). What knowledge is of most worth: Teacher knowledge for 21st century learning. Journal of digital learning in teacher education, 29(4), 127140.

[14] Mahmood Zuhdi Hj. Ab. Majid. 2001. Dinamisme Pengajian Syariah. Kuala Lumpur: Akademi Pengajian Islam, Universiti Malaya

[15] Marsh, D., \& Langé, G. (2000). Using languages to learn and learning to use languages. Finland: University of Jyväskylä.

[16] Merriam, Sharan B. 2001. Qualitative Research and Case Study Applications in Education. Revised and Expanded from" Case Study Research in Education. JosseyBass Publishers, 350 Sansome St, Sa n Francisco, CA 94104.

[17] Mwathwana, M. I., Mungai, C., Gathumbi, A. W., \& George, G. E. (2014). An analysis of History teaching methodology in High schools: A case of Tigania and Igembe districts, Meru County, Kenya. Journal of Education and Practice, 5, 83-88.

[18] Nor, N. H., Suhaimi, N. S., Wahab, N. S. A., Ismail, M. K. C., Noh, M. A. C., \& Razak, K. A. (2016, January). Pelaksanaan KBAT Dalam Pengajaran dan Pembelajaran Pendidikan Islam Sekolah Menengah: Satu Tinjauan Di Putrajaya. In Proceeding 7th International Seminar on Regional Education (Vol. 1, pp. 361375).

[19] Rahman, A. A., Zulkifli, M. S., Hashimee, M., Wazir, A., \& Sayed, M. (2019). Tahap Kompetensi Guru Bahasa Arab Di SABK Di Malaysia: Satu Dimensi. e-Bangi, 16(2).

[20] Remillard, J. T.. 2000. Can curriculum materials support teachers' learning? Elementary School Journal, 100(4): 331350

[21] Rosli, F. F., Ramli, M. A., \& Fatah, F. A. (2019). Penerimaan Pelajar Institut Pendidikan Guru (IPG) terhadap Elemen 
Fiqh Semasa dalam Kursus Pendidikan Islam [Students Acceptance of the Teacher Education Institute (IPG) on Current Fiqh Elements in Islamic Education Courses]. Jurnal Islam dan Masyarakat Kontemporari, 20(1), 29-48.

[22] Rusdin, N. M., \& Ali, S. R. (2019, November). Amalan dan Cabaran Pelaksanaan Pembelajaran Abad Ke-21. In Proceedings of the International Conference on Islamic Civilization and Technology Management (Vol. 23, p. 24).

[23] Serragiotto, G. (2017). The Problems of Implementing CLIL in Italy. International Journal of Linguistics, 9(5), 82.

[24] Shulman, L.S. 1987. Knowledge and Teaching: Foundations of New Reform Harvard Educational Review, Vol 57 (1): 122

[25] Sidek, D., Ab Rahman, R., Thoarlim, A., \& Zakaria, M. B. (2018). Effectiveness of Subject Islamic Shariah Education to Student's Interaction (Keberkesanan Mata Pelajaran Pendidikan Syariah Islamiah Terhadap Pergaulan Pelajar). Malaysian Journal of Islamic Studies (MJIS), 2(1), 2542.

[26] Silverman, David. 2013. Doing qualitative research: A practical handbook. SAGE publications limited,

[27] Siti Afifah Munirah Salleh, Ummu Dhabitah Binti Fadzir \& Kamarulzaman Abdul Ghani. 2017. Pelaksanaan KBD di SABK Kelantan berdasarkan persepsi pelajar: satu tinjauan awal, Prosiding Seminar kebangsaan Pengajaran dan Pembelajaran Bahasa Arab (SEBAR) 2017. hlm. 644-656.

[28] Suwannoppharat, K. \& Chinokul, S.. (2015) Applying CLIL to English language teaching in Thailand: Issues and challenges. Latin American Journal of Content and Language Integrated Learning. 8(2): 237254.

[29] Venville, G., Rennie, L. J., \& Wallace, J. (2012). Curriculum integration:
Challenging The Assumption of School Science as Powerful Knowledge. In Second international handbook of science education (pp. 737-749). Springer, Dordrecht.

[30] Yin, R. 2002. Case study research: Design and methods Ed ke 3. Thousand Oaks, CA: Sage. Publications. 